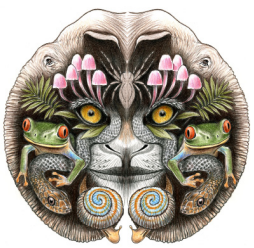

ISSN

Online 0974-7907

Print 0974-7893

OPEN ACCESS

\title{
NEW RECORDS OF OPISTHOBRANCHS FROM LAKSHADWEEP, INDIA (MOlLusCA: Heterobranchia)
}

\author{
Deepak Apte ${ }^{1} \&$ Vishal Bhave ${ }^{2}$
}

1,2 Bombay Natural History Society, Hornbill House, Mumbai, Maharashtra 400001, India ${ }^{1}$ spiderconch@gmail.com (corresponding author), ${ }^{2}$ vishalbhave@gmail.com

Abstract: All India Coordinated Project on Taxonomy (AICOPTAX), an initiative of Ministry of Environment and Forests allowed the authors to study opisthobranch fauna of the west coast of India. During the present study, nine species of opisthobranchs are reported for the first time from Lakshadweep of which six are new records to India.

Keywords: AICOPTAX, Heterobranchia, Lakshadweep, Mollusca, opisthobranch.

A careful literature search has revealed about 127 species of opistobranchs reported untill 2008 on the western coast of India by various authors. However, since 2008 after the systematic work undertaken by the authors several new records have been established (Apte 2009, 2012; Apte et al. 2010; Apte \& Salahuddin 2011; Bhave \& Apte 2011, 2013). The present study was undertaken through the All India Coordinated Project on Taxonomy - Mollusca supported by Ministry of Environment and Forests, Government of India.

The past work on opisthobranchs of the western coast of India was by Gardiner (1903), Winckworth (1946a,b), Hornell (1909b), Gideon et al. (1957), Narayanan (1968, 1969, 1971a,b), Menon et al. (1970), Rao \& Kumari (1973); Rao et al. (1974); Balani \& Patel (1994), and Jagtap (2009). Gosliner (1995) and Jensen (1992) reviewed the family Elysidae (now Plakobranchidae) from the Indo-Pacific region. Rudman (1983) studied
Chromodoris aspersa colour group.

\section{Materials and Methods}

Intertidal survey was done using snorkelling to collect the specimens. Direct search under dead coral boulders and shallow pools during low tides was conducted particularly on the eastern side reef. Digital images were taken of live specimens; specimens were stored in $90 \%$ ethyl alcohol after studying the morphological characters for DNA sequencing without relaxing them. The specimens are deposited in the Bombay Natural History Society (BNHS) collections.

Study site and duration: Field collections were carried out for two weeks in December 2009 and April 2010 at Minicoy $\left(8^{\circ} 16^{\prime} \mathrm{N} \& 73^{\circ} 3^{\prime} \mathrm{E}\right)$ and Kavaratti $\left(10^{\circ} 33^{\prime} \mathrm{N}\right.$ \& $\left.72^{0} 36^{\prime} \mathrm{E}\right)$, Lakshadweep Archipelago (Fig. 1).

\section{Results and Discussion}

During the two week survey, nine species were recorded belonging to eight families (Table 1). Apte (2009) reported 60 species of opisthobranchs from Lakshadweep of which 52 were new records to Lakshadweep and 40 new records to India. During the present work an additional nine new records were established for Lakshadweep of which six are new for India. This clearly reflects the fact that opisthobranch

DOI: http://dx.doi.org/10.11609/JoTT.o3487.5562-8 | ZooBank: urn:Isid:zoobank.org:pub:5DE10A7E-5F26-45BE-AFOB-31976F62789A

Editor: C. Raghunathan, Zoological Survey of India, Port Blair, India.

Date of publication: 26 March 2014 (online \& print)

Manuscript details: Ms \# 03487 | Received 15 January 2013 | Final received 09 December 2014 | Finally accepted 20 February 2014

Citation: Deepak Apte \& Vishal Bhave (2014). New records of opisthobranchs from Lakshadweep, India (Mollusca: Heterobranchia). Journal of Threatened Taxa 6(3): 5562-5568; http://dx.doi.org/10.11609/JoTT.03487.5562-8

Copyright: (C) Apte \& Bhave 2014. Creative Commons Attribution 3.0 Unported License. JoTT allows unrestricted use of this article in any medium, reproduction and distribution by providing adequate credit to the authors and the source of publication.

Funding: Ministry of Environment and Forests, Government of India.

Competing Interest: The authors declare no competing interests.

Acknowledgements: Authors are thankful to MoEF for providing financial support through AICOPTAX. Dr. J.R. Bhatt provided constant encouragement. Dept. of Environment and Forests, Lakshadweep Administration has been always supportive. Salahuddin V.K assisted during the field work. 


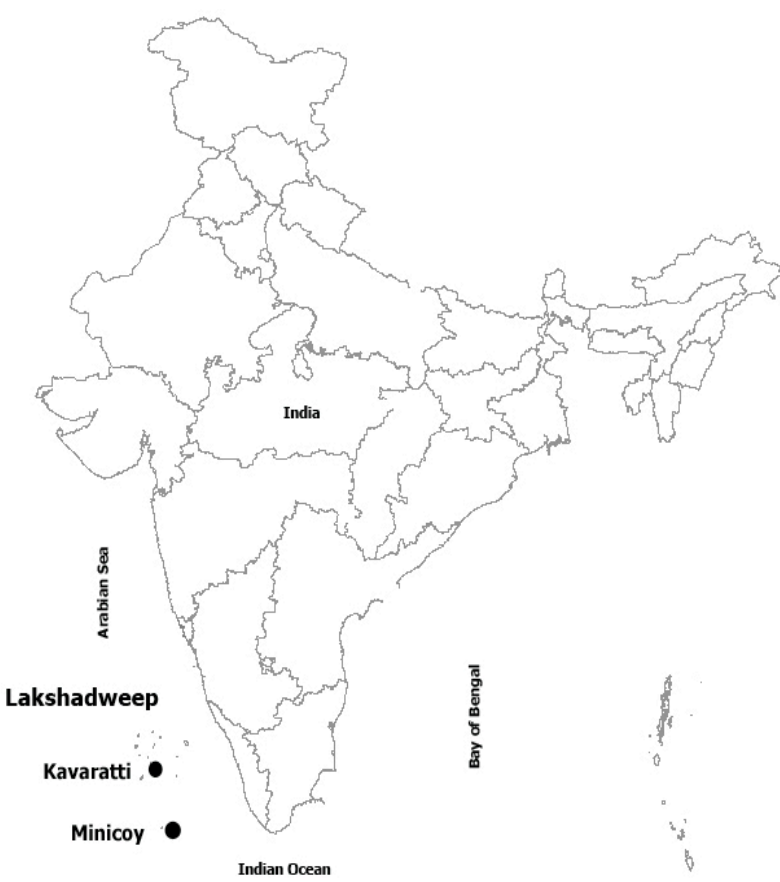

Figure 1. Survey locations in the Lakshadweep (map not up to the scale)

fauna need much more attention.

December 2, 2009 was an exceptional day due to the presence of very high density of species like Elysia tomentosa, Gymnodoris okinawae and Polybranchia orientalis at Kavaratti. Almost invariably, egg cases of $E$. tomentosa were seen in close proximity of egg cases of $P$. orientalis. Similar observations were made on 23 October 2007 where Gymnodoris ceylonica timed their appearance with the congregation of the benthic form of Stylocheilus longicauda [previously known as Stylocheilus striatus (Quoy \& Gaimard, 1932)] (Yonow 2012) on which they were seen feeding. Large congregations of Haminoea cymbalum were observed for three winter seasons on 4 December 2005, 29 January 2007 and 3 February 2008; which were breeding congregation. Large numbers of Flabellina bicolor were seen on 1 March 2009 and Dolabrifera dolabrifera on 9 December 2007. Similar observations were made by Yonow (2012) in La Réunion on February 2007 where H. cymbalum were seen at a density of 100 individual/ $\mathrm{m}^{2}$. Walter (1890) observed large congregation of Haminoea hydatis and Aplysia punctata at Plymouth. Carefoot (1987) in the review paper on the biology of Aplysia states that not all such aggregations are strictly for breeding, it is possible to happen due to successful settlement or even when a large number of individuals eat all available food and start moving towards new sources. Though there is no pattern in such occurrences,
Table 1 New records of opisthobranch from Lakshadweep

\begin{tabular}{|l|l|l|c|c|}
\hline & Family & Species & $\begin{array}{c}\text { New record to } \\
\text { Lakshadweep }\end{array}$ & $\begin{array}{c}\text { New record } \\
\text { to India }\end{array}$ \\
\hline 1 & Limapontiidae & $\begin{array}{l}\text { Sohgenia } \\
\text { palauensis }\end{array}$ & $\mathrm{V}$ & $\mathrm{V}$ \\
\hline 2 & Plakobranchidae & Elysia rufescens & $\mathrm{V}$ & $\mathrm{V}$ \\
\hline 3 & Pleurobranchidae & $\begin{array}{l}\text { Pleurobranchus } \\
\text { forskalii }\end{array}$ & $\mathrm{V}$ & $\mathrm{V}$ \\
\hline 4 & Gymnodorididae & $\begin{array}{l}\text { Gymnodoris } \\
\text { okinawae }\end{array}$ & $\mathrm{V}$ & $\mathrm{V}$ \\
\hline 5 & Chromodorididae & $\begin{array}{l}\text { Chromodoris } \\
\text { aspersa }\end{array}$ & $\mathrm{V}$ & $\mathrm{V}$ \\
\hline 6 & Discodorididae & $\begin{array}{l}\text { Sclerodoris } \\
\text { apiculata }\end{array}$ & $\mathrm{V}$ & - \\
\hline 7 & Dorididae & Doris granulosa & $\mathrm{V}$ & - \\
\hline 8 & Bornellidae & Bornella stellifer & $\mathrm{V}$ & - \\
\hline 9 & Facelinidae & $\begin{array}{l}\text { Phidiana } \\
\text { semidecora }\end{array}$ & $\mathrm{V}$ & $\mathrm{V}$ \\
\hline & & & 9 & 6 \\
\hline
\end{tabular}

such events are not uncommon.

\section{Details of newly recorded species}

Kingdom: Animalia

Phylum: Mollusca

Class: Gastropoda

Subclass: Heterobranchia

Infra-class: Opisthobranchia Milne-Edwards, 1848

Order: Sacoglossa Ihering, 1876

Family: Limapontiidae

\section{Sohgenia palauensis Hamatani, 1991}

India: Kavaratti, Lakshadweep.

Global Distribution: Tropical Indo-West and NorthWest Pacific (Rudman 2002), Palau (Hamatani 1991), Indonesia (Nudipixel database), Tanzania, Papua New Guinea, Guam, Japan (Gosliner et al. 2008) and Marshall Islands (http://www.gastropods.com).

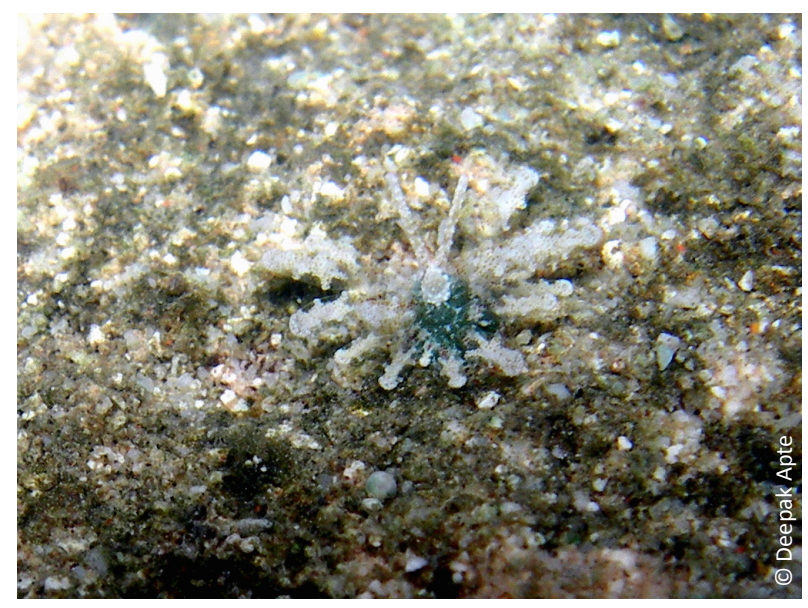

Image 1. Sohgenia palauensis 
Size: Single specimen. 8mm (BNHS-opistho-083).

Descriptive features: It is a small sea slug and rarely found, primarily due to its cryptic nature. The body is flattened with transparent cerata. Brownish-red dots are clearly visible on the cerata which are bulbous at the tips. The body is deep green in colour. Animal autotomizes cerata if disturbed (Image 1).

Status: Rare.

Family: Plakobranchidae

2. Elysia rufescens (Pease, 1871)

India: Kavaratti, Lakshadweep.

Global Distribution: Myanmar, Guam, Indonesia (Nudipixel), Australia, Tahiti, Hawaii, Reunion Island, Christmas Island, South Africa, Philippines, Samoa and Japan (Gosliner et al. 2008)

Size: Three specimens ranging between $20-40 \mathrm{~mm}$ (BNHS-opistho-90).

Descriptive features: During the survey, the species was found along with Elysia tomentosa. It is common in shallow exposed reef areas. The body is profusely mottled with white scattered acran olive green background. Edge of the parade has red band. Egg case is white in colour. The species has rarely been reported from western part of Indian Ocean (Gosliner 1987) (Image 2).

Status: Uncommon.

Order: Pleurobranchomorpha Schmekel, 1985

Family: Pleurobranchidae

3. Pleurobranchus forskalii (Rüppell \& Leuckart, 1831)

India: Kavaratti, Lakshadweep.

Global Distribution: Red Sea, Fiji, Australia, Indonesia,

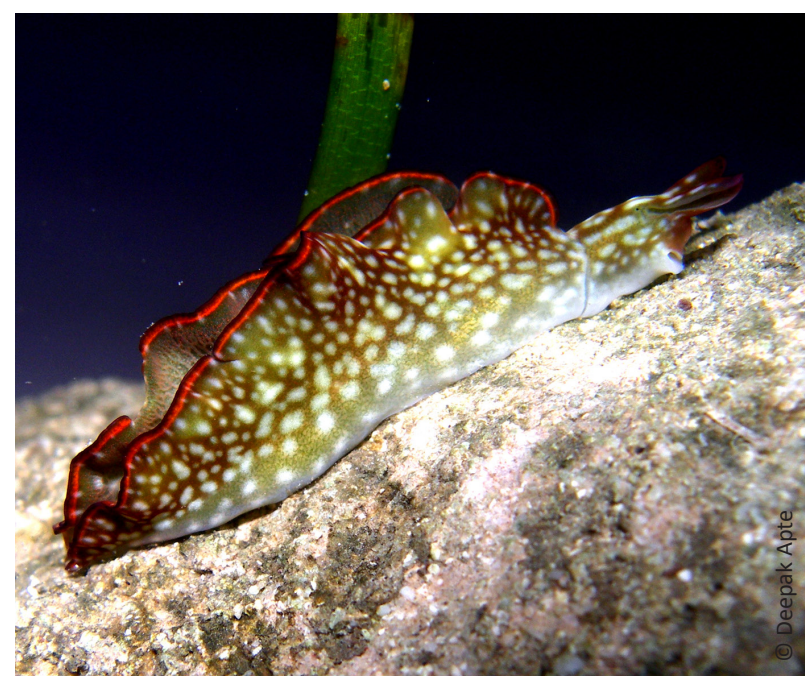

Image 2. Elysia rufescens
Philippines, Guam, Tanzania, New Guinea and Japan (Gosliner et al. 2008).

Size: Five specimens ranging between $20-72 \mathrm{~mm}$ (BNHS-opistho-580).

Descriptive features: It is a large sea slug and seen under coral boulders. It can also be seen moving on the sand floor. The surface is highly tuberculate. Each tubercle at the base is encircled by a bluish-violet colored ring. The species, however, show a wide range of colour variations. One of the specimens collected is deep reddish-orange and has no coloured rings at the base of tubercles. Both the colour forms are illustrated to show the colour variation seen in this species. Rhinophores have a fine rib like pattern. The foot is fleshy, muscular and large (Images 3 and 4).

Status: Seasonally common.

Order: Nudibranchia Cuvier, 1817

Family: Gymnodorididae
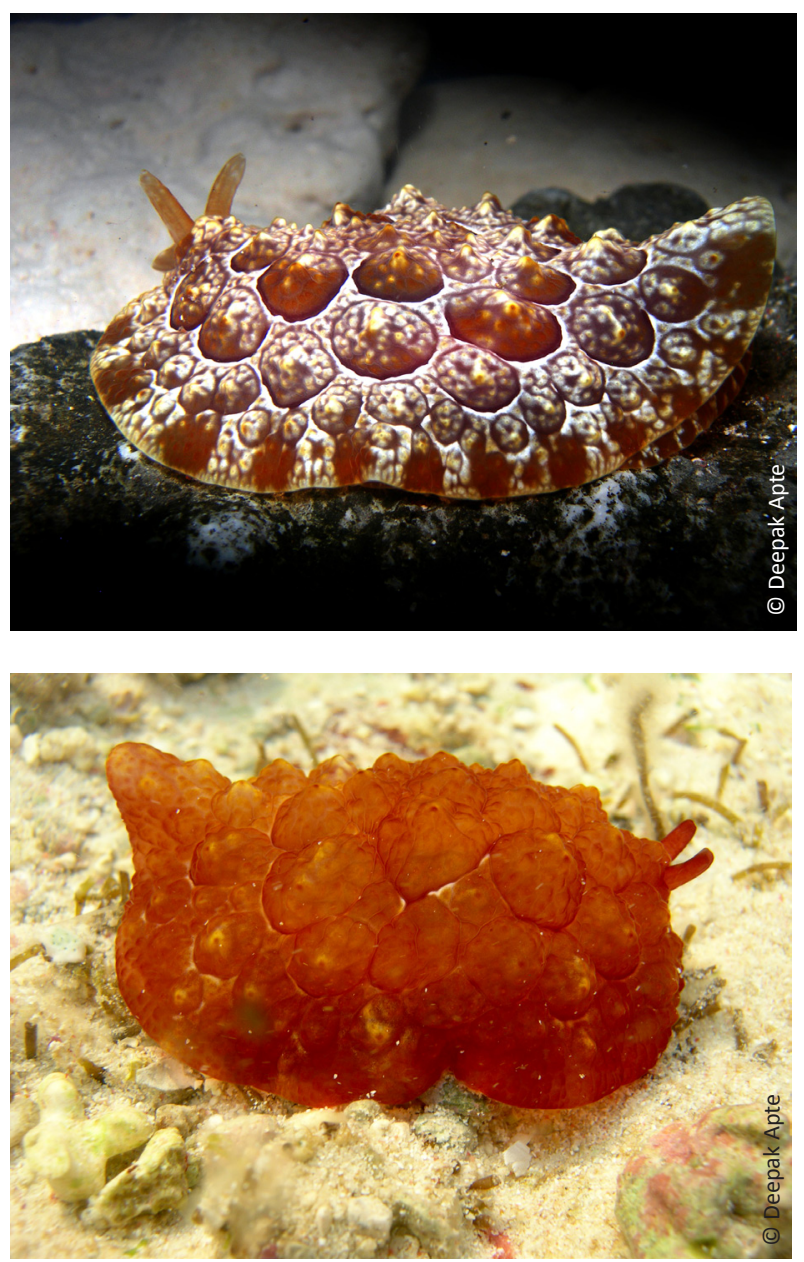

Image 3 \& 4. Pleurobranchus forskalii 


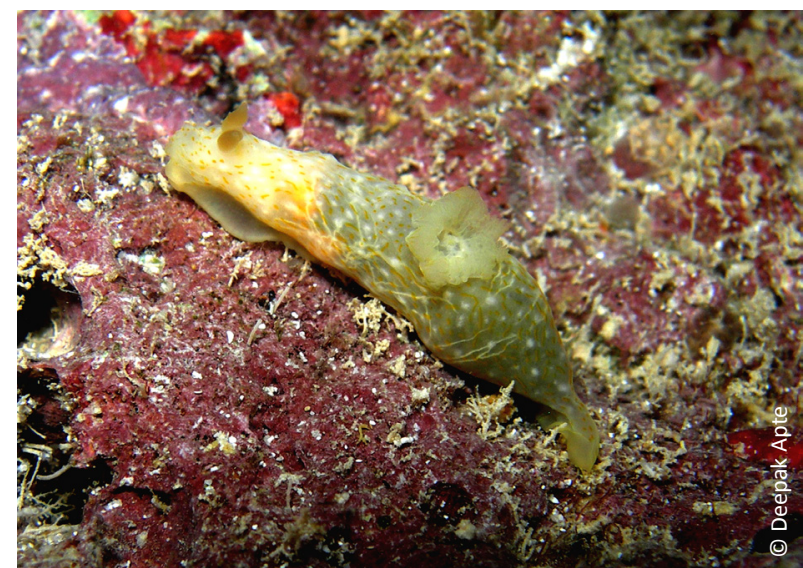

Image 5. Gymnodoris okinawae

\section{Gymnodoris okinawae Baba, 1936}

India: Kavaratti, Lakshadweep.

Global Distribution: Reunion, Aldabra, South Africa, Tanzania, Papua New Guinea, Philippines, Midway Atoll, Hawaii and Japan (Gosliner et al. 2008).

Size: Eight specimens ranging between $30-35 \mathrm{~mm}$ (BNHS-opistho-065).

Descriptive features: This species seems to have timed their appearance with those of Elysia tomentosa. Almost every specimen was seen with whole Elysia in its stomach (Image 4). On 2 December 2009, one of the author, Deepak Apte counted and measured size of over 800 individuals in a small area of about $100 \mathrm{~m}^{2}$. At the same time we counted Elysia tomentosa with average density of 90 individuals per $\mathrm{m}^{2}$. The congregation though was short-lived and both Gymnodoris and Elysia disappeared within a span of three days. Colour is light yellow spotted with white and orange. Body also has a scattered network of orange and white lines. Eight gills are clearly visible and form a complete circlet. Rhinophores are short and have 18-20 lamellae (Image 5).

Status: Seasonally common.

Family: Chromodorididae

5. Chromodoris aspersa (Gould, 1852)

India: Kavaratti, Lakshadweep.

Global Distribution: Indo Pacific from East Africa, Aldabra, Reunion Island, Seychelles, Papua New Guinea, Australia, Philippines, Marshall Islands, Japan and Hawaii (Gosliner et al. 2008).

Size: Five specimens measuring $16-33 \mathrm{~mm}$ (BNHSopistho-087).

Descriptive features: A mid-sized chromodorid and rarely seen. It is white in colour with deep violet spots on the body. Posterior end of foot is long, pointed and

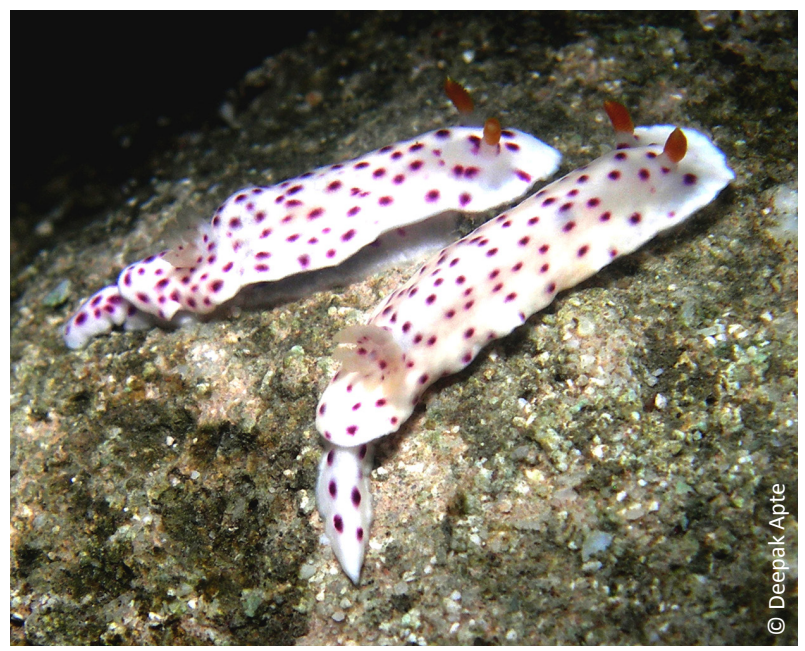

Image 6. Chromodoris aspersa

spotted with violet spots. Gills are translucent white and eight in number. Rhinophores are deep orange in colour and have 16-18 lamellae (Image 6).

Status: Uncommon.

\section{Family: Discodorididae}

6. Sclerodoris apiculata (Alder \& Hancock, 1864)

India: Kavaratti, Lakshadweep, Tamil Nadu and Andhra Pradesh. The species is described from Waltair, Andhra Pradesh as Doris apiculata by Alder \& Hancock. It was last recorded from Tamil Nadu in 1932 by C.H. O'Donoghue as Halgerda apiculata.

Global Distribution: Western Indian Ocean of South Africa, Madagascar, Saudi Arabia, Tanzania, Australia, Papua New Guinea and Japan (Gosliner et al. 2008).

Size: One specimen measuring $50 \mathrm{~mm}$ (BNHSopistho-061).

Descriptive features: Mantle of the species is like sponge on which it is found. Surface has deep pits. Mantle also has small tubercles which have white papillae. Larger tubercles have secondary papillae as well. Colour is yellow. Gills are bushy and light yellow in colour. Rhinophores has stout and dark yellow ochre. Foot margin is lined by distinct brownish-black line (Image 7).

Status: Rare.

Family: Dorididae

\section{Doris granulosa (Pease, 1860)}

India: Kavaratti, Lakshadweep and Ratnagiri (Maharashtra). It was originally described as Doriopsis granulosa by Pease, 1860 from Sandwich Islands.

Global Distribution: Western India Ocean (Madagascar, Seychelles, Reunion); Western Pacific, 


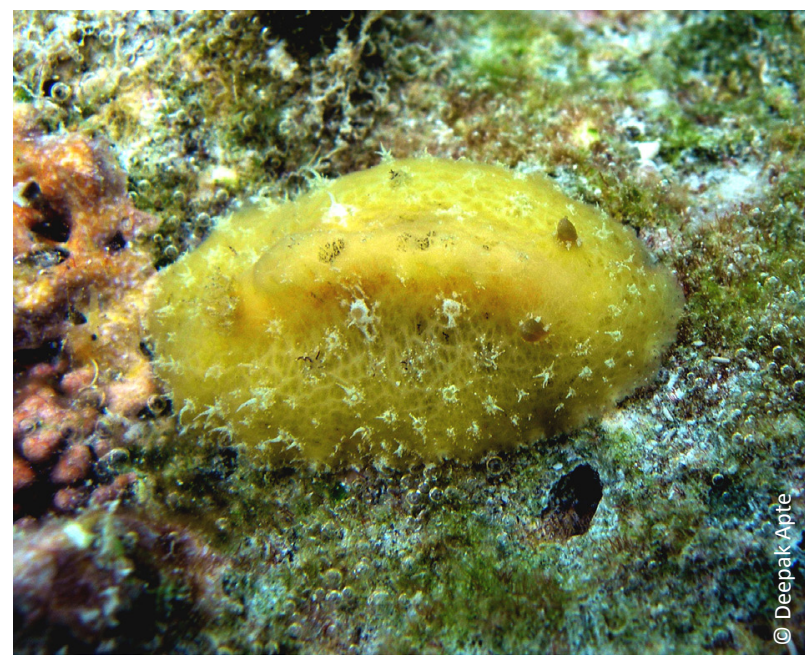

Image 7. Sclerodoris apiculata

Central Pacific, Marshall Islands and Hawaii.

Size: One specimen measuring $22 \mathrm{~mm}$ (BNHSopistho-879).

Descriptive features: Mantle of the animal bears small and rounded tubercles. Arrangement of gills is diagnostic in this species. Gills are arranged across the back in transverse line. Colour is dark yellow. Rhinophores are dark ochre yellow (Image 8).

Status: Rare.

Family: Bornellidae

8. Bornella stellifer (A. Adams \& Reeve, 1848)

India: Kavaratti and Agatti, Lakshadweep; Ratnagiri, Revdanda (Maharashtra) and Gulf of Kutch (Gujarat).

Global Distribution: Australia, Hawaii, Thailand, South Africa, Madagascar, Papua New Guinea, New Caledonia, Japan, Singapore, Malaysia, Indonesia, Taiwan, American Samoa, South China Sea, Korea, East Africa, Philippines, Tahiti, Hong Kong and Marshal Is (Pola et al. 2009).

Size: Three specimens. 25-29 mm (BNHSopistho-00637).

Descriptive features: A small sea slug found under coral boulders. Oral tentacles are paired and finger like. Gills are placed at the base of each cerata. Rhinophores are present on long stalks and surrounded by long filamentous papillae. It feeds on hydroids. The color is deep reddish-brown with white patches. Tips of cerata and papillae have an apical red band (Image 9).

Status: Rare at Lakshadweep but common in Gujarat and Maharashtra.

Remark: Specimens from Gujarat (Apte et al. 2010) and Lakshadweep varies significantly in

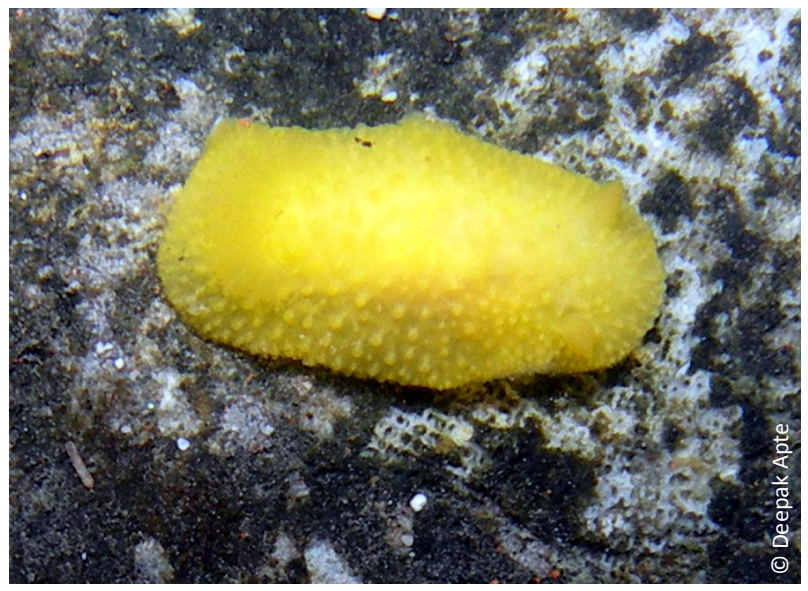

Image 8. Doris granulosa

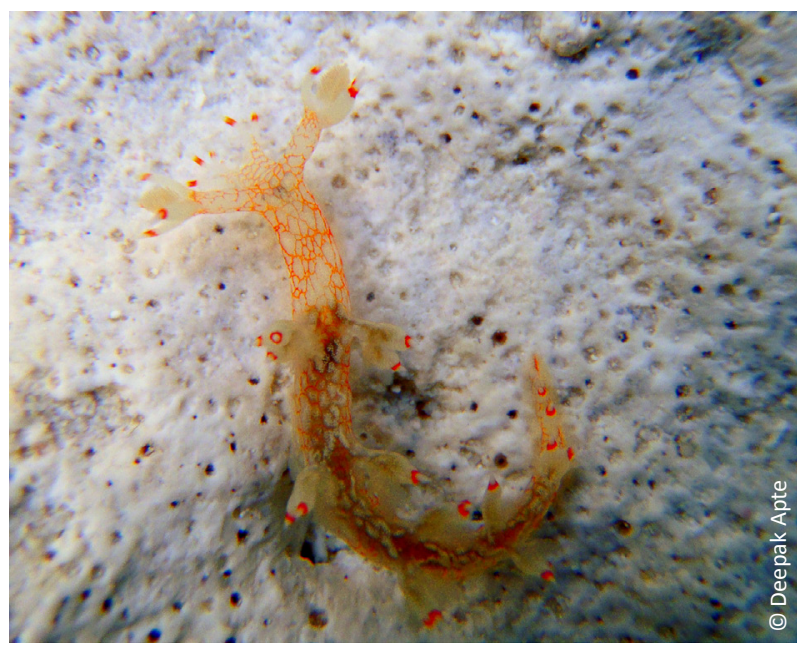

Image 9. Bornella stellifer

external morphology. The DNA based study was thus undertaken to confirm the identity of the species found in Lakshadweep. The studies confirmed it as Borrnella stelifer. Pola et al. (2009) did a revision of family Bornellidae and present findings confer with the same. DNA sequences for $\mathrm{Col}, 16 \mathrm{~s}$ and $\mathrm{H} 3$ are deposited with gene bank under GenBank accession number KF601556KF601558 (16S.sqn 637 KF601556, COI.sqn 637 KF601557, H3.sqn 637 KF601558).

Family: Facelinidae

9. Phidiana semidecora (Pease, 1860)

India: Kavaratti, Lakshadweep.

Global Distribution: Hawaii (Pease 1860) and Sagami Bay, Japan (Baba 1949, 1965).

Size: One specimen measuring $10 \mathrm{~mm}$ (BNHSopistho-880). 


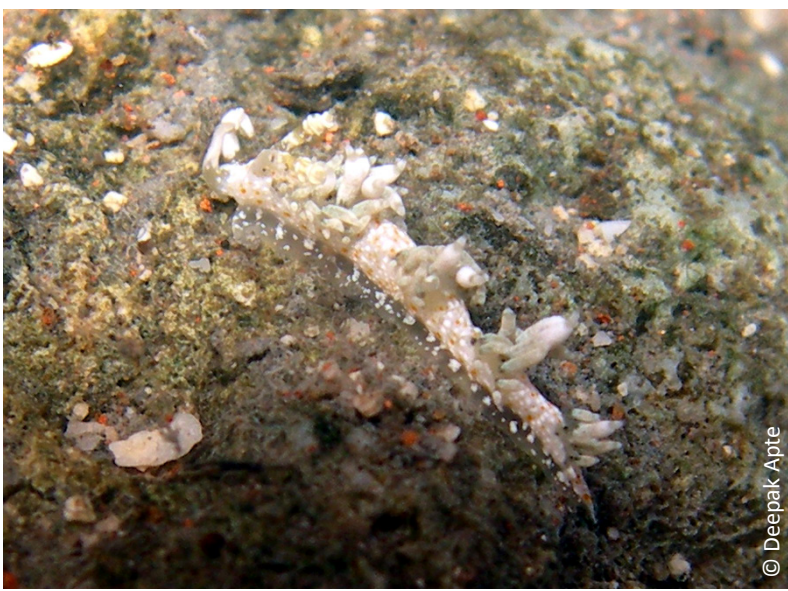

Image 10. Phidiana semidecora

Descriptive features: It is a small slug. It shows a close resemblance with $P$. anulifera. However, red lines as seen in $P$. anulifera are absent in this species. The mantle is translucent white and scattered with white and red spots. Foot is translucent white and heavily spotted with white. Rhinophores are annulated with 3-4 annulations with upper half opaque white. Oral tentacles are banded with opaque white and translucent red arranged in alternate manner with opaque red band at the base and at the center. Cerata are arranged in four clusters. Few cerata in each cluster are bulbous at the tip with an opaque white band just below the tip (Image 10).

Status: Rare.

In conclusion it can be said that the AICOPTAX initiative of Government of India has allowed strengthening taxonomic work on molluscs in general and opisthobranchs in particular. Previously, the authors reported 88 new records of opisthobranchs to Lakshadweep, Maharashtra and Gujarat which include 61 new records to India (Apte 2009; Apte et al. 2010; Bhave \& Apte 2011). The range extension of nine more species of opisthbranchs to Lakshadweep only reinforces the fact that more intensive surveys are essential as they can add more species to this archipelago. Diversity of cryptic opisthobranchs is virtually undocumented from these islands. Thus, targeted surveys of hydroid, bryozoan and sponge associated crypic opisthobranch may reveal new records and can be an important area of future studies.

\section{References}

Apte, D. \& V.K. Salahuddin (2011). Record of Hexabranchus sanguineus (Rüppell \& Leuckart, 1828) from Lakshadweep Archipelago, India. Journal of the Bombay Natural History Society 107(3): 261-262.

Apte, D. (2009). Opisthobranch fauna of Lakshadweep Islands, India with 52 new records to Lakshadweep and 40 new records to India. Part 1. Journal of the Bombay Natural History Society 106(2): 162175.

Apte, D. (2012). Field Guide to the Marine Life of India. Published by Animesh Apte, 504pp.

Apte, D., V. Bhave \& D. Parasharya (2010). An annotated and illustrated checklist of the Opisthobranch fauna of Gulf of Kutch, Gujarat, India with 21 new records for Gujarat and 15 new records for India. Part 1. Journal of the Bombay Natural History Society 107(1): 14-23.

Balani, M.C. \& B. Patel (1994). Occurrence of Elysia grandifolia (Mollusca, Gastropoda), and its radionuclide content from Tarapur Coastal Waters, West Coast of India. Indian Journal of Marine Sciences 23(1): 61-63.

Bhave, V. \& D. Apte (2011). Illustrated checklist of Opisthobranch fauna of Ratnagiri, Maharashtra, India with 8 new records to India. Journal of the Bombay Natural History Society 108(3): 172-182.

Bhave, V. \& D. Apte (2013). Current Status of Indian Opisthobranch Fauna: Chapter 5. Ecology and Conservation of Tropical Marine Faunal Communities. Springer-Verlag Berlin Heidelberg, 17pp (In Press).

Carefoot, T.H. (1987). Aplysia: its biology and ecology. Oceanography and Marine Biology 25: 167.

Gardiner, J.S. (1903). The Fauna and Geography of the Maldives and Laccadive Archipelagoes - Vol 2. Cambridge University Press, 1080pp.

Gideon, P.W., P.K.B. Menon, S.R.V. Rao \& K.V. Jose (1957). On the marine fauna of the Gulf of Kutch: A preliminary survey. Journal of the Bombay Natural History Society 54(3): 690-706.

Gosliner, T.M. (1987). Nudibranchs of Southern Africa. A Guide to Opisthobranh Molluscs of Southern Africa. Sea Challengers \& Jeff Hamann, Monterey \& El Cajon, California, 136pp.

Gosliner, T.M. (1995). The genus Thuridilla (Opisthobranchia: Elysiidae) from the tropical Indo-Pacific, with a revision of the phylogeny and systematics of the Elysiidae. Proceedings of the California Academy of Sciences 49(1): 1-54.

Gosliner, T.M., D.W. Behrens \& A. Valdes (2008). Indo-Pacific Nudibranchs and Sea Slugs: A Field Guide to The World's Most Diverse Fauna. Sea Challengers Natural History Books and the California Academy of Sciences, 426pp.

Hamatani, I. (1991). Sohgenia palauensis n. gen. \& sp., a new ascoglossan opisthobranch from the Palau Islands collected by the R/V Sohgen-Maru. The Venus, The Japanese Journal of Malacology 50(2): 85-92.

Hornell, J. (1909b). A note on the presence of symbiotic algae in the integuments of nudibranchs of the genus Melibe, pp. 145-148. In: Report to the government of Baroda on the marine zoology of Okhamandal 1.

Jagtap, T.G. (2009). Elysia bangtawaensis Swennen (Nudibranch) from the mangrove habitat of Mandovi Estuary, Goa (central west coast) India. Current Science 96(1): 30-33.

Jensen, K.R. (1992). Anatomy of some Indo-Pacific Elysiidae (Opisthobranchia: Sacoglossa = Ascoglossa), with a discussion of the generic division and phylogeny. Journal of Molluscan Studies 58(3): 257-296; http://dx.doi.org/10.1093/mollus/58.3.257

Menon, P.K.B., A.K. Dutta \& D.D. Gupta (1970). On the marine fauna of the Gulf of Kutch - Part II. Journal of the Bombay Natural History Society 58(2): 475-494.

Narayanan, K.R. (1968). On three opisthobranchs from the southwest coast of India. Journal of the Marine Biological Association of India 10(2): 377-380.

Narayanan, K.R. (1969). On the opisthobranchiate fauna of the Gulf of Kutch. Proceedings of the Symposium on Mollusca held at Cochin from January 12 to 16, 1968, Symposium Series 3 (1): 189-213; figs. 
1-20. Marine Biological Association of India, Mandapam Camp, India.

Narayanan, K.R. (1971a). On two doridacean nudibranchs (Mollusca: Gastropoda), from the Gulf of Kutch, new to the Indian coast. Journal of the Bombay Natural History Society 68(1): 280-281.

Narayanan, K.R. (1971b). On a species of the genus Berthellina (Opisthobranchia: Notaspidea) of the Gulf of Kutch. Journal of the Marine Biological Association of India 12(1-2): 210-212.

Nudipixel (2011). http://www.nudipixel.net/

Pola, M., W.B. Rudman \& T.M. Gosliner (2009). Systematics and preliminary phylogeny of Bornellidae (Mollusca: Nudibranchia: Dendronotina) based on morphological characters with description of four new species. Zootaxa 1975: 1-57.

Rao, K.V. \& L.K. Kumari (1973). On a new species of Dendrodoris ehrenberg from Goa: Mollusca-Nudibranchiata. Journal of the Marine Biological Association of India 15(1): 242-250.

Rao, K.V., P. Sivadas \& L.K. Kumari (1974). On three rare doridiform nudibranch molluscs from Kavaratti Lagoon, Laccadive Islands. Journal of the Marine Biological Association of India 16 (1): 113-125

Rudman, W.B. (1983). The Chrormodorididae (Opisthobranchia: Mollusca) of the Indo-West Pacific: Chrornodoris splendida.
C. aspersa and Hypselodoris placida colour groups. Zoological Journal of the Linnean Society 78: 105-173; http://dx.doi. org/10.1111/j.1096-3642.1983.tb00864.x

Rudman, W.B. (2002). Sohgenia palauensis Hamatani, 1991. [In] Sea Slug Forum. Australian Museum, Sydney. Available from http:// www.seaslugforum.net/factsheet/sohgpala

Walter G. (1890). A Complete list of the opisthobranchiate mollusca found at Plymouth; with further observations on their morphology, colours, and natural history. Journal of the Marine Biological Association of the United Kingdom (New Series), 1, pp. 399-457. http://dx.doi.org/10.1017/S0025315400057878

Winckworth, H.C. (1946a). Glossodoris from Bombay. Proceedings of the Malacological Society of London 26(6): 155-160.

Winckworth, H.C. (1946b). A new Goniodoris from Bombay. Proceedings of the Malacological Society of London 27(2): 59-61.

Yonow N. (2012). Opisthobranchs from the western Indian Ocean, with descriptions of two new species and ten new records (Mollusca, Gastropoda). ZooKeys 197: 1-129.

http://www.gastropods.com/9/Shell_50629.shtml accessed on 10th Sept 2013 